\title{
Joasaph II in an Unpublished List of the Metropolitans of the Ethiopian Church
}

\author{
Ekaterina V. Gusarova \\ Institute of Oriental Manuscripts, National Library of Russia, St. Petersburg \\ ekater-ina@mail.ru
}

\begin{abstract}
This article introduces new information regarding the Metropolitan Joasaph II (III) (the years of his tenure were 1770-1803). Josaph II (III), the Coptic clergyman, was the head of the Ethiopian Church for 33 years. His service coincided with the initial stage of one of the most complicated period in the history of the Ethiopian Church. This period was marked by the almost complete collapse of the Christian kingdom on the Horn of Africa. The main source comprising these data is the hitherto unknown list of the Metropolitans of Ethiopia, which contains the unique data about Joasaph II. It was discovered in an unpublished manuscript of the monastery Däbrä Damo in the province of Təgray in northern Ethiopia and analyzed by the present author. The result of this analysis is obvious: a modern reader receives a trustworthy portrait of this ambitious person who, in spite of his efforts was not able to terminate the long-standing schism in the Ethiopian Church. His efforts, however, left fond memories of himself among his flock.
\end{abstract}

\section{Keywords}

Ethiopian Church - Metropolitan of Ethiopia - Church hierarchy - King of Ethiopia Täklä Giyorgis I - political disintegration on the Horn of Africa - abunä Joasaph II.

* This article is an output of the research project "Minority and Majority in the Asian-African Area: 'Ethics' vs "Efficiency" in the Context of Socio-Cultural Interaction," implemented as part of the Basic Research Program at the National Research University Higher School of Economics (HSE). 
Up to AD 1958 the Ethiopian Church was formally an integral part of the Coptic Church. It is known, that since the Middle Ages the Ethiopian kings kept sending a special embassy to Egypt with rich gifts for Muslim authorities and Coptic Hierarchs of Egypt. This embassy was a formal act to request a permission to set a new Metropolitan for the Ethiopian Church. The embassies were usually facing a long and difficult way through territories of Nubia or by the Red sea. These efforts and a toil of the journey, however did pay off: a newly set Metropolitan was instrumental in managing the Church affairs, especially the ordination of the new priests.

The Ethiopian Church considered the status of the Ethiopian kings to be sacred and legitimate. In their turn the kings provided to the Church material support, including land and property, ${ }^{1}$ as well as granted to it the education monopoly. The archimandrites, influential abbots and the court clergy constituted an integral part of the state apparatus of the Christian kingdom in Ethiopia. The Church remained deeply rooted in the socio-political context of the Kingdom. It did even participate in territorial expansion along with the monarch and his army. It was instrumental in baptizing of the pagan dwellers on the recently acquired territories.

The status of the Metropolitan sent from the Coptic Church was rather unusual especially within the context of the already historically established relations between the Ethiopian state and the Church. As an envoy from the Coptic Church he always remained a foreigner within the Ethiopian society and had no access either to the State affaires or the internal Church politics. A Metropolitan was nominally the supreme head of the Ethiopian Church, but in reality his decisions remained to be of limited importance.

Historically the Ethiopian society has never been homogenous but multiethnic and polyconfessional. Theological disputes, which occasionally led to the real schism, due to this diversity were usually generated "at home" and as a consequence, bore local features. ${ }^{2}$ In such periods the Church, instead of being an integrating factor, that would normally work towards the unification of the State, became one of the main reasons for its disintegration. In the second half of the eighteenth century just before the arrival of the new Metropolitan

1 See for instance: R. Pankhurst, State and Land in Ethiopian History, Addis Ababa, 1966.

2 The most considerable of those disputes in the history of Ethiopia during the 18th cent. was this which existed between the supporters of two doctrines: that of the "unity" (Täwahədo) and that of the "anointment" (Qabat). Due to their dissemination the first of them was known as the doctrine of Däbrä Libanos and the second one - as the faith of Təgray (see, for instance: Tedros Abraha, "Qəbat," in: $E A E, 4$, 2010, pp. 267-270; Idem, "Täwaḥədo," in: $E A E$, 4, 2010, pp. $873-875)$. 
Joasaph II in Ethiopia some centrifugal tendencies became clearly visible. The country was torn into pieces by the enormous ambitions of its feudal lords. In the local historiography this period, which lasted approximately from 1769 till

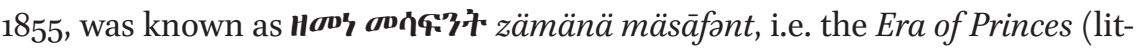
erally Era of Judges). This is an obvious pun to the Biblical Book of Judges which narrates about the Ancient Israel being divided into separate often independent tribes, that underwent numerous disasters. The Ethiopian kings of the period of zämänä mäsāfant, the last representatives of the Gondärine branch of the so called Solomonic dynasty, did not enjoy much influence or power. They were merely nominal rulers as opposed to the really influential and powerful local magnates. These, on the contrary, did manage to amass a great deal of wealth and material resources, including weapons. In terms of the military support they well relied upon various tribal chiefs and their people from all over the country.

Joasaph (Yosab) II was known as the 104th Metropolitan of Ethiopia. He took his office in 1770 and served up to his death in $1803 \cdot{ }^{3} \mathrm{He}$ was enthroned on the metropolitan see following the death of his predecessor John (Yohannəs) III. ${ }^{4}$ During his office Joasaph II took part in coronation of different kings, among them Iyasu III (1784-1788), Bäədä Maryam II (1794-1795) and Solomon (Sälomon) II (III) (1796-1797, 1799). There is, however, no information that he took part in the enthronement of Täklä Giyorgis I (1779-1784, 1788-1789, 17941795, 1795-1796, 1798-1799, 1800-1801), although this fact cannot be completely excluded.

The name of Joasaph II as the formal head of the Ethiopian Church together with some biographic details pertaining to the 33 years of his service have been preserved in the different texts. These texts include the lists of the Metropolitans of Ethiopia and the chronicles regarding the reign of the King Täklä Giyorgis I as well as other kings and local rulers. ${ }^{5}$ Some data can be also found in

See about him in: S. Ancel, "Yosab II," in: $E A E$, 5, 2014, pp. 94-95; S. Tedeschi, "Yosāb II (d. 1803)," in: The Coptic Encyclopedia, ed. A. S. Atiya, Vol. 3, New York - Toronto, 1991, pp. 1030-1032. The original spelling of his name as Yosab goes back to the Arabic Coptic tradition.

4 According to the lists of the Metropolitans of Ethiopia, the name Yosab (Joasaph) was borne by the 39th, goth and 104th Metropolitans of Ethiopia. Since the information about the $39^{\text {th }}$ is uncertain, the 104th Metropolitan is usually called Yosab II.

5 The text of these chronicles included in the larger compilation is preserved in three main copies: Orient. 820 (W. Wright, Catalogue of the Ethiopic Manuscripts in the British Museum acquired since 1847, London, 1877, pp. 314-315), Orient. 821 (Ibid., pp. 315-318) kept in the British Library, and Éth. 143 from the Bibliothèque nationale de France (H. Zotenberg, Catalogue des manuscrits éthiopiens (gheez et amharique) de la Bibliothèque nationale, 
the manuscript marginalia, official invocation formulae and some notes and remarks of economic character, which preserved there. ${ }^{6}$

For a long time were known only four manuscripts containing the list of the Metropolitans of Ethiopia. Two of them are nowadays kept in the British Library, ${ }^{7}$ one in the Bibliothèque nationale de France ${ }^{8}$ and one more was brought to Italy by a capuchin missioner P. Léon des Avanchers in the second part of the nineteenth century. ${ }^{9}$ These very texts were examined by Ignazio Guidi in detail. ${ }^{10} \mathrm{He}$ came to a conclusion that in fact originally there were two different versions of this list: the larger one ${ }^{11}$ and the shorter one. ${ }^{12}$ I. Guidi prepared and published both versions accompanied by commented translation in Italian. ${ }^{13}$ The first and second versions are different not just with regard to their size, but also to the historical data which they comprise. The shorter version provides the list of the names of the 26 Metropolitans. It ends with the story about $a b b a^{14}$ Isaac and $a b b a$ Mark, who arrived in Ethiopia together in 1481 accompanied by a group of Coptic clerics. ${ }^{15}$ These names are supplied with some sporadic biographical data. The biographical data are limited to

Paris, 1877 , pp. 216-221), - and in two manuscripts of less importance (copied especially for European travellers): Rüppell 18 and d'Abbadie 118 kept now in the University Library in Frankfurt am Main (L. Goldschmidt, Die Abessinischen Handschriften der Stadtsbibliothek zu Frankfurt am Main (Rüppell'sche Sammlung), Berlin, 1897, S. 63-67) and the Bibliothèque nationale de France (A. d'Abbadie, Catalogue raisonné de manuscrits éthiopiens, Paris, 1859, pp. 133-136). As to the edition of the chronicles related to the 'Era of Princes' with an English translation (The Royal Chronicle of Abyssinia 1769-1840, with transl. and notes by H. Weld Blundell, Cambridge, 1922), it is of insufficient quality.

There are several manuscripts kept in the British Library in which Joasaph II is frequently mentioned. To the larger extent they have been brought in 1868 from Mäqdäla.

Orient. 812 (Wright, Catalogue of the Ethiopic Manuscripts, pp. 290-291) and Orient. 769 (Ibid., pp. 320-321). The list of the Metropolitans from Orient. 769 is edited in the catalogue (Ibid., p. 320).

8 Éth. 160 (Zotenberg, Catalogue des manuscrits éthiopiens, p. 263).

9 Its current location is unknown.

10 See about him in: L. Ricci, "Guidi, Ignazio," in: $E A E$, Vol. 2, 2005, pp. 908-909.

$11 \quad$ Attested in Éth. 160 and Orient. 812.

12 Attested in Orient. 769 and in the manuscript of P. Léon des Avanchers.

13 I. Guidi, "Liste dei Metropoliti d'Abissinia," Bessarione, ser. 1ª, 6 (1899), pp. 1-16.

$14 A b b a$ (the father) or abunä (our father) are honorable titles of the Metropolitan (pappas) of Ethiopia. The official title of the metropolitan of the Ethiopian Church was pappas, borrowed from Greek, where it means "father" (S. Kaplan, "Pappas," in: $E A E$, Vol. 4, 2010, pp. 113-114; D. Nosnitsin, “Abunä”, in: $E A E$, Vol. 1, 2003, p. 56).

Such a rare case in the history of Ethiopia can be explained by the will of the King Zär'a Ya'əqob (1434-1468) and his successors to obtain the autocephaly of the Ethiopian Church. 
such events, as death and burials of the hierarchs or their simultaneous tenures. The authors of the lists gave an accurate number of the Metropolitans, albeit in some cases their names cannot be established. ${ }^{16}$

Contrary to the shorter version the larger one (reflected in two lists) has preserved the history until the 107th Metropolitan, abba Sälama, who was the head of Ethiopian Church from 1841 until his death in 1868. It is well known that the manuscript Orient. 769, kept in the British Library was written for the ruler of Shoa (Šäwa) Śahlä Śəlasse (1806-1847), one of the princes whose reign coincides with the period of political decentralization. There is no continuation of this list: abba Sälama was still alive at that time.

The number of the lists of the Ethiopian Metropolitans known to I. Guidi can nowadays be enlarged by another one. ${ }^{17}$ It was discovered in 2010 by the team of Ethio-SPaRe ${ }^{18}$ project in the library of the monastery Däbrä Damo or Anda Aragawi located in the province of Təgray in northern Ethiopia; where it is still preserved. The importance of this monastery cannot be overestimated: it is known to be one of the earliest monastic centers in the country. ${ }^{19}$

This list constitutes an integral part of the codex of Synaxarion where it is transcribed on ff. 35v, col. $2.15-$ f. $36 \mathrm{r}$, col. 3.28. It comprises the entries for the Metropolitans from abba Sälama (Frumentius) to $a b b a$ Athanasius, the 107th Metropolitan as it comes from the calculation of the author of this list. Abba Athanasius became the head of the Ethiopian Church in 1869, soon after the death of the King Theodore (Tewodros) II (1855-1868). ${ }^{20}$ The manuscript itself is dated from the time of the King Ggwäla Șiyon (1801-1818) and the list of the Metropolitans was subsequently added in the empty folios. At the beginning of the list of the Metropolitans there is a marginal note stating that the text was compiled in the times of the "King of Kings Yohannəs", who is to be identified as John IV (1872-1889). The list was made a part of the codex of the Synaxarion more than 60 years after it was transcribed.

The list of the Metropolitans from the manuscript DD-020 is clearly longer than other four edited by I. Guidi, however, not considerably, because it contains the name of only one Metropolitan more. Nevertheless this unique

16 According to the shorter list (from $a b b a$ Sälama (Frumentius) up to $a b b a$ Isaac and $a b b a$ Mark) by the beginning of the 16 th century the total number of the Metropolitans was 65 .

17 DD-020 (C3-IV-265) Synaxarion, Däbrä Damo, Təgray; Hamburg University, Digital Oriental Manuscript Library, (photo Ethio-SPaRe project 2010).

Ethio-SPaRe project was held from 2010 to 2014 by Dr. D. Nosnitsin at the Hiob Ludolf Center for Ethiopian Studies at Hamburg University.

Tsegay Berhe G. Libanos, "Red. Däbrä Damo," in: $E A E$, Vol. 2, 2005, p. 17-20.

20 Seven years later $a b b a$ Athanasius himself passed away in 'Adwa or, according to another opinion, was murdered by order of the King John IV. 
addition makes the manuscript to be the most complete with regard to the biographic data of the Metropolitans. The first part of the list contains only the names of the Metropolitans and their reciprocal numbers. However, from the 95th Metropolitan, i.e. Simeon and onwards the author starts providing some more detailed information. It should be stressed here that the tenure of Simeon coincided with the crucial period in the Ethiopian history marked with the conversion of the King Susənyos (1607-1632) into the Roman Catholic faith. This event did take place in 1624. The Metropolitan Simeon himself was killed in a battle between Susənyos and the rebels, who defended the traditional faith of Alexandria.

The arrival of Joasaph II in Ethiopia and his subsequent occupation of the Metropolitan see was described in the chronicle of Mika'el Səhul (ca. 16911777). He was an influential nobleman, who managed by 1769 (when he killed the King Iyo'as I (1755-1769)) to take the control over the country. Since the King Täklä Haymanot II came to power, Mika'el Səhul became really powerful and had almost the absolute authority. In that period, for the first time in the Ethiopian history, was compiled a royal chronicle, which in the first instance did not deal with the legitimate King, but with a powerful feudal lord, viz. Mika'el Səhul.

Joasaph II, who arrived in Ethiopia in 1770, clashed with the despotic rule of this lord. Traditionally the Metropolitans resided in Gondär, which was the capital city since its foundation in 1636. Mika'el Səhul, however, tried to change this tradition. He persuaded the newly arrived Metropolitan to stay with him in the north of Ethiopia, in the province of Təgray. The city of Gondär remained empty: before the Metropolitan arrived there Mika'el Səḥul left Gondär together with the King and went towards the north. According to the royal historiographer, on his arrival Joasaph met in the capital different noblemen and military chiefs who hesitated in making decision and taking notice of what to do and how to act in such circumstances. Joasaph was completely unaware, who was the head of the State, and the locals did not know what to advise him in this unclear situation.

Another important issue for the Metropolitan was the necessary material support. In such an unstable situation Joasaph, first of all, was preoccupied with his own survival and, in the second place, with the management of the Ethiopian Church. In describing these events the chronographer was even unable to find the appropriate words and instead of giving his opinion just relied upon the Divine Mercy. In reality, however, Joasaph was materially fully dependent on this influential feudal lord and as a sequence had to become his servant. As a result the Church in such a disintegrated country ceased to be the strong supporter for the royal power. In that situation the Metropolitan, as the 
whole Church, was not treated with any respect and Joasaph II had to become a subject to suffer and grief.

The crisis of the Christian Ethiopian state inevitably entailed a crisis in traditional royal historiography. The chroniclers of Mika'el Səḥul and Täklä Giyorgis I mention Metropolitan Joasaph rather unfrequently. A modern reader cannot escape an impression that the leader of the Church in most cases did not actively participate in political and religious life of the country. In this way, after the story of the arrival of Joasaph II on June 18, 1770, he is mentioned again after 10 years period for the date of November 1,1780 . The occasion the Metropolitan was mentioned in the chronicle was the military campaign of the King Täklä Giyorgis against the rebels when he and the açḉäg $e^{21}$ gave the King their blessings. These rebels resisted the enthronement of the monarch. One of them fled to the territories traditionally belonged to Oromo tribes. A clear perspective to fight also the Oromo people made the King's situation rather difficult, as his people could still remembered the sad events of the midsixteenth century, when the spontaneous migration of the Oromo warriors to inner territories of the Horn of Africa began. ${ }^{22}$

At the end of 1780 started a period of the relative internal stability in the country. During this time the Metropolitan Joasaph received better attention of the historiographer and was more frequently mentioned in the royal chronicle. This clearly indicates that his role in State and Church affairs became more prominent. Apart from sending gifts to the Emperor as a token of his attention there were established regular audiences between him and the sovereign. On June 30, 1782 Täklä Giyorgis I arrived in the residence of the Metropolitan accompanied by high-ranking clerics. ${ }^{23}$ The schism in the Ethiopian Church again threatened the integrity of the State and the power of the monarch, both considerably weakened by numerous incessant rebellions of feudal lords. Due to the fact that the principal purpose of Täklä Giyorgis I in the initial period of his first reign was the unification of the torn into pieces

21 Originally the title was given to the abbot of the monastery of Däbrä Libanos, who by the Gondärine epoch became the real head of the Ethiopian Church. So the local ačç̌ăge, but not the foreign Metropolitan, was the most influential figure in the Church administration. These officials are often mentioned together in the royal chronicles.

See about that people and their migrations: P. T. W. Baxter, "Galla," in: $E A E$, Vol. 2, 2005, pp. 66o-661; J. Hultin, "Oromo ethnography," in: EAE, Vol. 4, 2010, pp. 59-61; Ezekiel Gebissa, "Oromo history," in: $E A E$, Vol. 4, 2010, pp. 61-64; J. Hultin, "Perceiving Oromo. 'Galla' in Great Narrative of Ethiopia," in: Being and becoming Oromo, Uppsala, 1996, pp. 81-91.

23 The reason for that official visit was the long lasting dispute between the supporters of the doctrines of the "unity" and of the "anointment" in the Ethiopian Church (see n. 3 above). 
Ethiopia, the support of the Metropolitan no doubt was of great importance for him. In its turn this step of the King was very significant also to abunä Joasaph. For the first time since his ascension to the see 12 years ago he was honored with the sovereign's favor and consideration.

From that moment onwards special banquets in presence of state and court officials and monks from the main Ethiopian monastic centers took regular place at the residence of the Metropolitan. Soon Joasaph II became a well known peacemaker for the dissenters both in the Church and in the State. His efforts were acknowledged by the King who made a special banquet in Joasaph's honor. It did take place in the Metropolitan residence and was well attended by the rival theologians. However, in the reality all the measures to reconcile both parties, including long speeches of the açç̣agge, had no positive effect. Finally Joasaph II, who was well versed in religious matters, realized that this dispute was just a fruit of speculations of local theologians and had nothing in common with the official doctrine of the Coptic Church. The Ethiopian Church as its integral part had to follow the decisions of the Coptic theologians. In 1801 Joasaph became tired of his attempts to reconcile the dissenters and anathematized both parties. The "Jugement Day" was on the threshold. The turbulence and rebellion among the clergy of Gondär took place to such an extent that the Metropolitan was compelled to go into exile on one of the lake Tana islands. In order to regain his position of the head of Ethiopian Church he had to renounce the anathema. With a heavy heart Joasaph finally realized that in this Christian African country, which used to be isolated for so long, its own customs always took priority. Therefore very little could be changed by one unfortunate foreigner, whoever he was, even the Metropolitan himself!

Joasaph II served by participating in the Täklä Giyorgis I policy to diminish the influence of Oromo (mostly Polytheists or Muslims) in the Christian Ethiopian state. This policy even resulted in a military campaigns against the Oromo tribes who lived to the south-east of Gondär in 1782-1783.

After the end of the last reign of Täklä Giyorgis I the powerful noblemen and princes were busy claiming the leadership in the country. They paid very few attention to the Church matters, and even less to its Coptic Metropolitan. Joasaph II's efforts to restore the peace and ecclesiastical order were not successful.

In September of 1793 a new upheaval in Gondär happened. Several rebellious groups arrived to the capital claiming the power. The royal residence was burned. Armed conflicts in the streets threatened the inhabitants of the city. The Metropolitan and the aççäge unsuccessfully tried to reason the people. But their words went into sand. 
The everlasting struggle and rivalry facilitate frequent changes of persons on the throne. The fact was not to the Metropolitan's liking, however, he had to accept both the fact and the rulers and sometimes did even participate in their coronations. Such a situation was completely alien to the concept of the sacred status of an anointed king, which led to re-iterating protests from the hierarch. As a result, he was jailed sometime between the late May - first half of June of 1799. He stayed in jail for an unknown period and on his release he became fully indifferent to everything. Probably Joasaph II has adopted this attitude as he was concerned with maintaining his own status, especially due to the fact that the situation in the capital was more or less stable. He stopped to pay attention to the problems of the Ethiopian Church and did not make any attempt to get involved into political games of powerful magnates.

When at the end of November of 1799 Täklä Giyorgis appeared again in Gondär, the Metropolitan, who remembered the terrifying stories of the past, as well as the strength and bravery of that monarch became very crossed with him. The author of the chronicle cited a part of his long speech on this occasion: "What is the reason of thy coming here, while thou art a pagan? Thou got thy deserts, if the God would have destroyed both thee and the rulers of Begämdar

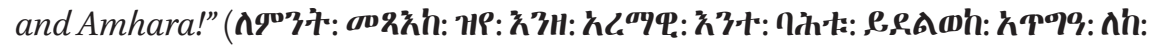

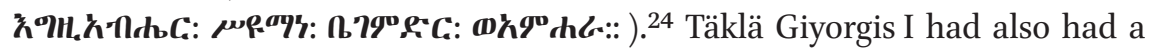
metamorphosis. Previously a God-fearing builder of cathedrals he eventually had lost every respect for the Church and religion and even began to rob church treasures for mercenary motives.

One needs to add that the Metropolitan Joasaph II received frequent mentions both in the texts of the chronicles and their margins as well (these texts to a larger extent are being preserved in the British Library). He also received mentions in the texts of prayers. ${ }^{25}$ In some manuscript copies can be even found personal signatures of the Metropolitan with laudatory formulae, written in Coptic and in Arabic, as well as the impressions of his seal. ${ }^{26}$ It seems here very possible that these manuscripts originally were property of the main Ethiopian monasteries, which Joasaph II used to visit during his service.

The Metropolitan of the Ethiopian Church Joasaph II passed away on September 11, 1803 in Gondär. According to the Church tradition, he was buried in

24 See, for instance: Orient. 821, fol. 575r, col. 1.25-2.5; Éth. 143, fol. 359r, col. 1.7-11. Bägemdər (Begämdər) and Amhara are two important regions of Central Ethiopia. In Bägemdər lays the capital Gondär of the late medieval Ethiopia.

25 See, for example, Orient. 80 (Wright, Catalogue of the Ethiopic Manuscripts, pp. 91-92).

26 Orient. 511, fol. 2v (Wright, Catalogue of the Ethiopic Manuscripts, p. 26); Orient. 778, fol. 2v (Ibid., pp. 235-254). Unfortunately those impressions are not readable. 
the church of St. Gabriel in the special district of the capital, called betä abun "the house of the Metropolitan", not far from the residence of the ačçäge.

His death gave birth to a story of legendary character, which can be found both in the lists of the Metropolitans ${ }^{27}$ and in the royal chronicle of Ethiopia. ${ }^{28}$ The story runs as follows: "After his (Joasaph II. - E. Gusarova) death, on the 7 th day, the light descended on his grave, so that the priests, who were here to make the funeral service for him, were frightened and prostrated themselves. And all the people (lit.world) contemplated the light at night, after the cock-crow. And in the times of his life he (Joasaph II. - E. Gusarova) performed numerous miracles" (ס

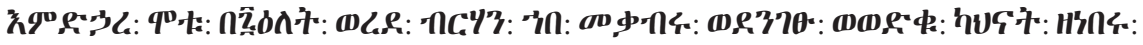

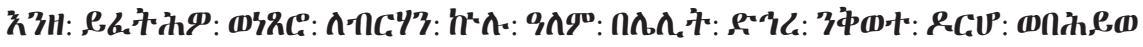

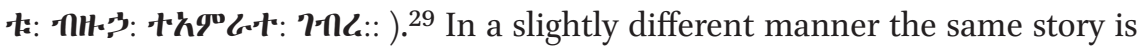
retold in the text of the chronicle by the historiographer: "On the 2oth of the month (Nähase; August 24 (12), ${ }^{30}$ 1803. - E. Gusarova) the moon was of blood colour ... Mäskäräm began on Sunday (September 11 (August 30), 1803. - E. Gusarova) ... On that day abunä Joasaph passed away and was buried at St. Gabriel. On the 5 th day of the month (September 15 (3). - E. Gusarova) in the middle of the night the light descended on his grave. I was not in the area, but those, who were in the area and who saw and heard, related it to me" ('⿳亠口冋: :

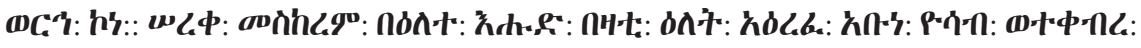

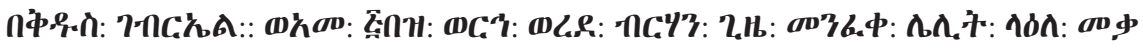

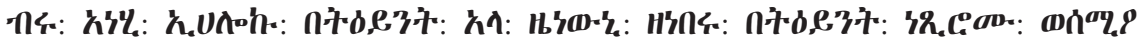
ob-::). 31

According to the common opinion on Joasaph II expressed in the different sources, examined in the article, he left fond memories in hearts of his flock. People loved and respected him and the royal chronicler was often calling him a "great righteous man". One has to add here that the concept of light was of special importance in the Ethiopian Christology and proved to be widely used on different occasions of religious character. In this context it is very significant that the light descended on the tomb of that virtuous man.

\footnotetext{
27 See above n. 8-10.

28 See above n. 6.

29 DD-020, fol. 36r, col. 2.27-33.

30 Here and below the dates are given according to the Gregorian calendar, while their correspondences in the Julian one are taken in brackets. Orient. 821, fol. 58or, col. 2.16-3.10; Éth. 143, fol. 362v, col. 1.8-19.
} 